\title{
PENGARUH IMPLEMENTASI KEBIJAKAN NILAI PENAWARAN DI BAWAH 80 \% TERHADAP KUALITAS PEKERJAAN KONSTRUKSI DI KABUPATEN BANDUNG
}

\section{THE EFFECT OF UNDER $80 \%$ BIDDING POLICY IMPLEMENTATION ON THE QUALITY OF CONSTRUCTION WORK IN BANDUNG REGENCY}

\author{
Asep Subrata ${ }^{1}$, Mas Halimah ${ }^{2}$, Mohammad Benny Alexandri ${ }^{3}$ \\ Program Pascasarjana Kebijakan Publik \\ Fakultas Ilmu Sosial dan Politik \\ Universitas Padjadjaran \\ subrataasep07@gmail.com¹, mas.halimah@unpad.ac.id², bennyalexandri@yahoo.co.id ${ }^{3}$
}

\begin{abstract}
ABSTRAK
Tujuan dari penelitian ini adalah untuk mengetahui pengaruh dari implementasi kebijakan nilai penawaran di bawah 80 \% terhadap kualitas pekerjaan konstruksi di Kabupaten Bandung. Metode yang digunakan dalam penelitian ini menggunakan teknik analisis deskriptif yang bersifat asosiatif kausal yaitu menggambarkan pengaruh dari variabel bebas (independent variable) terhadap variabel terikat (dependent variable) dengan menggunakan analisis statistik uji-t, dan uji-f. Sampel dalam penelitian ini menggunakan teknik probability sampling sebanyak 48 responden terhadap Pejabat Pembuat Komitmen (PPK) kegiatan jasa konstruksi. Hasil temuan menunjukan bahwa implementasi kebijakan dari segi organisasi, interpretasi, dan penerapan mempunyai pengaruh yang signifikan dengan arah positif, artinya kalaupun implementasi kebijakannya diperbaiki, dan dimensi variabel dari organisasi ditingkatkan, interpretasinya diperbaiki, dan penerapannya diperbaiki maka akan mempengaruhi kualitas pekerjaan konstruksi menjadi lebih baik. Dimana besaran peresentase nilai koefisien determinasi (Adjusted R-Square) diperoleh sebesar 87,7 \% sedangkan sisanya sebesar (1-R2) =12,3 \% dijelaskan oleh sebab-sebab lain diluar model, dengan besaran pengaruh dari masing-masing variabel untuk organisasi 18,4 $\%$, interpretasi $46,6 \%$, dan penerapan $23,5 \%$.
\end{abstract}

Kata kunci : Implementasi, Penawaran di bawah 80 \%, Kualitas Pekerjaan Konstruksi

\begin{abstract}
The purpose of this study as to determine the effect of the implementation of the bid value policy below 80 \% On the quality of construction work in Bandung Regency. The method used in this study uses descriptive analysis techniques that are causal associative, which describes the effect of the independent variable on the dependent variable using statistical analysis t-test and f-test. The sample in this study used a probability sampling technique to the Commitment Making Officer (PPK) of construction service activities. The findings show that the implementation of policies in term of organization, interpretation, and application has a significant effect in a positive direction, meaning that even if the policy implementation is improved, and the variable dimensions of the organization are improved, the interpretation is improved, and the application is improved, it will affect the quality of construction ork for the better. Where the percentage value of the coefficient of determination (Adjusted R-Square) is obtained at $87,7 \%$ while the remaining $(1-R 2)=12,3 \%$ is explained by other causes outside the model, with the magnitude of the influence of each variable for the organization $18,4 \%$, interpretation $46,6 \%$, and application $23,5 \%$.
\end{abstract}

Key word : Implementation ,Under $80 \%$ Bidding, Quality of Construction Work. 


\section{PENDAHULUAN}

\section{Latar Belakang Masalah}

Pengadaan barang/jasa pemerintah adalah merupakan suatu rangkaian tahapan kegiatan pengadaan barang/jasa yang dilakukan oleh

Kementerian/Lembaga/Perangkat Daerah yang menggunakan anggaran baik yang bersumber dari APBN/APBD. Dimulai sejak dari identifikasi kebutuhan atau perencanaan sampai dengan serah terima hasil pekerjaan, tertuang dalam Perpres Nomor 16 Tahun 2018 pasal 3.

Dimana tujuan umum pengadaan barang/jasa merupakan salah satu upaya pemerintah dalam mewujudkan pembangunan nasional, mendorong perekonomin global, serta diharapkan prosesnya dapat berjalan sesuai dengan tujuannya. Dimana tujuan tersebut dapat diterapkan melalui proses pengadaan dengan prinsip antara lain : (i) untuk penyederhanaan prosedur menjadi lebih efektif, (ii) efisiensi anggaran, (iii) transparan, terbuka, dan bersaing untuk mendorong persaingan usaha yang sehat, (iv) berlaku adil yaitu dapat memberdayakan dan melindungi usaha kecil, (vi) dan akuntabel.

Tahapan penting dalam proses tender pekerjaan jasa konstruksi adalah proses penetapan pemenang tender, berdasarkan Perpres Nomor 16 Tahun 2016 Pasal 39 angka (4), menyatakan bahwa : Harga terendah merupakan metoda evaluasi penawaran Penyedia Barang/Pekerjaan Konstruksi/Jasa Lainnya yang memenuhi persyaratan teknis.

Transformasi proses tender dalam penetapan pemenang tidak hanya harga terendah yang responsif, melainkan mendukung terhadap pemenuhan nilai manfaat yang sebesar-besarnya (value for money) dalam menghasilkan barang/jasa yang tepat dari setiap uang yang dibelanjakan harus dapat berkualitas dan terukur.

Berdasarkan data sekunder dari UKPBJ Kabupaten Bandung, untuk tender jasa konstruksi yang dilaksanakan dari tahun 2017 s.d 2019, didapatkan total jumlah paket pekerjaan jasa konstruksi sebanyak 652 paket pekerjaan, nilai penawaran di atas $80 \%$ sebanyak 604 paket pekerjaan, dan untuk nilai penawaran terendah di bawah $80 \%$ sebanyak 48 paket pekerjaan. Disajikan dalam tabel 1.1 sebagai berikut :
Tabel 1.1 Jumlah Tender Jasa Konstruksi Periode Tahun 2017 s.d Tahun 2019

\begin{tabular}{|c|l|c|c|c|}
\hline \multirow{2}{*}{ No } & \multicolumn{2}{|c|}{ Uraian } & \multicolumn{3}{|c|}{$\begin{array}{c}\text { Jumlah Paket Tender Pekerjaan } \\
\text { Jasa Konstruksi (Paket/Tahun) }\end{array}$} \\
\cline { 2 - 5 } & 2017 & 2018 & 2019 \\
\hline 1 & $\begin{array}{l}\text { Jumlah Paket Pekerjaan } \\
\text { Nilai Penawarannya } \geq \text { di } \\
\text { atas 80\% }\end{array}$ & 130 & 288 & 186 \\
\hline 2 & $\begin{array}{l}\text { Jumlah Paket Pekerjaan } \\
\text { Nilai Penawarannya }< \\
\text { atau di bawah 80 \% }\end{array}$ & 14 & 16 & 18 \\
\hline Jumlah Total Paket Tender & 144 & 304 & 204 \\
\hline
\end{tabular}

Sumber : Diolah oleh peneliti data dari UKPBJ Kabupaten Bandung, Tahun 20172019

Sebaran nilai penawaran di bawah 80 $\%$ paket pekerjaan tender jasa konstruksi di kabupaten Bandung tersebar di beberapa perangkat dinas. Disajikan dalam gambar 1.5, antara lain :

Gambar 1.5 Sebaran Jumlah Paket Pekerjaan

Nilai Penawaran Di Bawah 80 \% Di Pemerintah Daerah Kabupaten Bandung

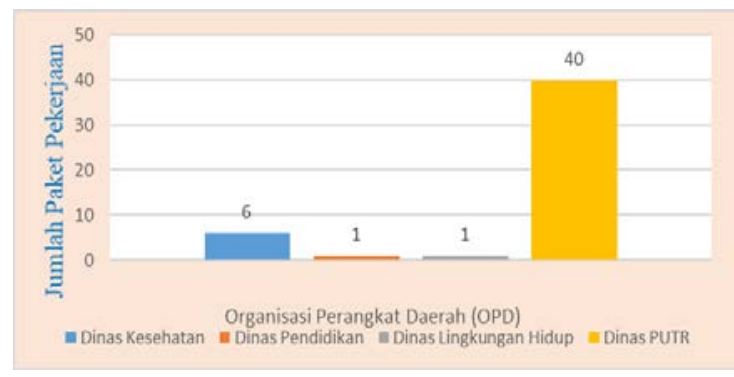

Sumber : Diolah oleh penulis data dari UKPBJ Kabupaten Bandung, Tahun 20172019

Hasil studi pendahuluan bahwa penawaran di bawah $80 \%$ dalam tender jasa konstruksi berpengaruh terhadap kualitas pekerjaan, karena perencanaan pekerjaan konstruksi sesuai Peraturan Menteri Pekerjaan Umum Nomor : 04/PRT/M/2009 perencanaan pekerjaan untuk jasa konstruksi sudah dihitung berdasarkan keahlian dan ditunjang berdasarkan data-data yang dapat dipertanggung jawabkan. Meliputi : Spesifikasi Teknis, Rencana Kerja dan Syarat, dan Harga Perkiraan Sendiri (HPS) menjadi acuan atau batasan penawaran dari penyedia 
untuk menawar pekerjaan yang responsif dan relevan. Dimana penawaran peserta juga harus mengikuti ketetapan, diantaranya : (i) harga satuan berdasarkan harga pasar, (ii) telah memperhitungkan keuntungan dan biaya tidak langsung (overhead cost) ditambah pajak pertambahan nilai (PPN), (iii) dan penetapan HPS berlaku paling lama 28 (dua puluh delapan) hari kerja sebelum batas akhir untuk : (a) pemasukan dokumen penawaran untuk pemilihan dengan pascakualifikasi, (b) pemasukan dokumen kualifikasi untuk pemilihan dengan prakualifikasi.

Dimana pelaksanaan tender jasa konstruksi di Pemerintah Daerah Kabupaten Bandung mengacu kepada Peraturan Menteri PUPR Nomor 14 Tahun 2020, dalam pelaksanaan dan penerapan kebijakan tersebut terdapat permasalahan yang menjadi hambatan, diantaranya sebagai berikut :

1. Kurangnya pemahaman dari pelakau pengadaan (SDM) yang meliputi pelaku pengadaan tentang pengadaan barang/jasa.

2. Model kebijakan pengadaan barang/jasa adalah top-down melalui LKPP dan Kementerian terkait, sehingga masih diperlukan adaptasi dan koordinasi dari perumus sampai implementor antar OPD.

\section{Rumusan Masalah}

Dari uraian diatas, maka rumusan masalah dalam penelitian ini adalah “ seberapa besar pengaruh implementasi kebijakan nilai penawaran di bawah $80 \%$ terhadap kualitas pekerjaan konstruksi di Kabupaten Bandung”.

\section{Tujuan Penelitian}

Adapun capaian yang ingin peneliti dapatkan dari penelitian ini adalah "untuk mengetahui pengaruh dari implementasi kebijakan nilai penawaran di bawah $80 \%$ terhadap kualitas pekerjaan konstruksi di Kabupaten Bandung”.

\section{TINJAUAN PUSTAKA}

\section{A. Implementasi Kebijakan}

Merilee S. Grindle (1980) dalam AG Subarsono (2015:93) keberhasilan suatu implementasi kebijakan dapat diukur atau dilihat dari proses dan pencapaian tujuan hasil akhir (output), yaitu tercapai atau tidaknya tujuan-tujuan yang ingin diraih. Dimana keberhasilan implementasi menurut Grindle dipengaruhi oleh dua variable besar, yakni oleh isi kebijakan (content of policy) dan lingkungan implementasi (context of implementation).

Ada dua faktor utama dalam proses implementasi kebijakan, yakni faktor utama internal meliputi kebijakan yang akan diimplementasikan dan faktor-faktor pendukung dan faktor utama eksternal yang meliputi kondisi lingkungan dan pihak-pihak terkait.

Said Zainal Abidin (2016:165) mengemukakan bahwa kondisi kebijakan merupakan faktor yang paling utama dan dominan dalam proses implementasi dari sebuah kebijakan karena yang diimplementasikannya justru kebijakan itu sendiri. Berhasil atau tidaknya dari implementasi kebijakan ditentukan oleh dua hal, yaitu kualitas kebijakan dan ketepatan strategi.

Charles O Jones (1994:296) dalam melaksanakan implementasi sebuah program kebijakan yang berisi tindakan yang diusulkan oleh pemerintah dalam rangka mencapai sasaran yang ditetapkan yang pencapainnya problematis. Dapat dikatakan bahwa penerapan atau implementasi dari sebuah program adalah suatu kegiatan yang dimaksudkan untuk mengoperasikan atau pelaksanaan kebijakan yang memerlukan Tindakan-tindakan yang sistematis. Menurut Charles O. Jones ada tiga macam aktivitas kegiatan yang perlu diperhatikan, antara lain :

1. Organisasi : Pembentukan atau penataan kembali sumberdaya, unit-unit, serta metode agar kebijkan dapat berjalan sesuai dengan tujuan dan sasaran kebijakan guna memberikan hasil atau dampak yang diinginkan.

2. Interpretasi : Menafsirkan atau penjelasan dari sebuah substansi kebijakan agar program kebijakan mudah dipahami, sehingga menjadi sebuah rencana dan 
pengarahan yang tepat, serta dapat diterima serta dilaksanakan oleh para pelaku dan sasaran kebijakan.

3. Penerapan : Ketentuan rutin dari pelayanan, pembayaran atau lainnya yang disesuaikan dengan tujuan atau perlengkapan implementasi dari program kebijakan.

\section{B. Penawaran Harga Pengadaan Barang/Jasa}

Pengadaan Barang/Jasa Pemerintah terbaru diatur dalam Peraturan Presiden Nomor 16 Tahun 2018 merupakan peraturan pengganti Peraturan Presiden sebelumnya beserta petunjuk teknisnya, dikarenakan Peraturan Presiden sebelumnya disadari masih terdapat kekurangan dan belum menampung perkembangan kebutuhan pemerintah mengenai pengaturan atas Pengadaan Barang/Jasa yang baik. Peraturan Lembaga Kebijakan Pengadaan Barang/Jasa Pemerintah Nomor 9 Tahun 2018 tentang Pedoman Pelaksanaan Pengadaan Barang/Jasa melalui Penyedia, serta Peraturan Menteri Pekerjaan Umum Dan Perumahan Rakyat Republik Indonesia Nomor 07/PRT/M/2019 tentang Standar Dan Pedoman Pengadaan Jasa Konstruksi Melalui Penyedia sebagaimana dirubah menjadi Peraturan Menteri Pekerjaan Umum Dan Perumahan Rakyat Republik Indonesia (Permen PUPR) Nomor 14 tahun 2020 tentang Standar Dan Pedoman Pengadaan Jasa Konstruksi Melalui Penyedia.

Tender adalah metode pemilihan yang dilakukan secara elektronik (e-procuremnet) melalui sistem aplikasi SPSE, secara umum sistem pengadaan barang/jasa di bagi dua, yaitu : (i) e-purchasing untuk pengadaan dan pembelian barang, dan (ii) e-tendering (tender) untuk pemilihan penyedia Barang/Pekerjaan Konstruksi/Jasa Lainnya. Khususnya untuk tender pekerjaan konstruksi menggunakan metode tender Pascakualifikasi Satu File-Harga Terendah Sistem Gugur. Dimana yang menjadi pemenang tender adalah penawaran harga paling terendah yang memenuhi persyaratan administrasi, kualifikasi, teknis, dan biaya sesuai dengan yang telah dipersyaratkan dalam standar dokumen pemilihan. Tender merupakan metode pemilihan untuk mendapatkan penyedia barang/pekerjaan konstruksi/jasa lainnya. Sedangkan seleksi adalah metode pemilihan untuk mendapatkan penyedia jasa konsultansi.

Harga Perkiraan Sendiri (HPS) adalah perkiraan harga barang/jasa yang ditetapkan oleh Pejabat Pembuat Komitmen (PPK), dimana penetapan HPS paling lama 28 (dua puluh delapan) hari kerja sebelum batas akhir untuk :

(1) Pemasukan penawaran untuk pemilihan dengan pascakualifikasi; atau

(2) Pemasukan dokumen kualifikasi untuk pemilihan dengan prakualifikasi.

Menurut Mustofa Kamal (2011) Widyaiswara di Pusdikatwas BPKP Riwayat HPS harus didokumentasikan secara baik, dimana pengertian HPS adalah harga Barang/Jasa yang dikalkulasikan secara keahlian dan berdasarkan data yang dapat dipertanggungjawabkan. Nilai total HPS terbuka dan tidak rahasia, yang dimaksud dengan nilai total HPS adalah hasil perhitungan seluruh volume pekerjaan dikalikan dengan harga satuan ditambah dengan seluruh beban pajak dan keuntungan. Berdasarkan HPS yang ditetapkan oleh PPK, ULP/Pejabat Pengadaan mengumumkan nilai total HPS, dimana rincian harga satuan dalam perhitungan HPS bersifat rahasia dan besarnya keuntungan dan biaya overhead maksimal $15 \%$ dari HPS.

Dimana harga perkiraan sendiri (HPS) digunakan sebagai :

(1) Alat untuk menilai kewwajaran harga penawaran dan/atau kewajaran harga satuan;

(2) Dasar untuk menetapkan batas tertinggi penawaran yang sah dalam pengadaan barang/pekerjaan konstruksi/jasa lainnya; dan

(3) Dasar untuk menetapkan besaran nilai jaminan pelaksanaan bagi penawaran yang nilainya lebih rendah $80 \%$ (delapan puluh persen) dari nilai HPS;

Harga terendah dalam penawaran adalah merupakan metode evaluasi yag digunakan untuk pengadaan barang/pekerjaan konstruksi/jasa lainnya dalam hal penawaran harganya yang menjadi dasar untuk penetapan 
pemenang diantara penawaran yang memenuhi persyaratan administrasi dan teknis

\section{Kualitas Pekerjaan Konstruksi}

Menurut istilah kata kualitas berarti mutu, yaitu tingkat baik buruknya sesuatu. Akan tetapi banyak pakar dan organisasi yang mencoba mendefinisikannya berdasarkan sudut pandangnya masing-masing.

Berdasarkan sudut pandang mengenai pengertian kualitas dari para ahli maka penulis menarik kesimpulan untuk kualitas adalah kesesuaian persyaratan dengan spesifikasi barang atau pekerjaaan yang ditawarkan dengan hasil pekerjaan berikut barang atau produk untuk memuaskan kebutuhan yang diinginkan oleh pemilik pekerjaan.

Berdasarkan Undang - Undang Republik Indonesia Nomor 2 Tahun 2017 tentang Jasa Konstruksi mendefinisikan sebagai berikut :

(1) Pekerjaan Konstruksi adalah keseluruhan atau sebagian kegiatan yang meliputi pembangunan, pengoperasian, pemeliharaan, pembongkaran, dan pembangunan kembali suatu bangunan;

(2) Pengguna Jasa adalah pemilik atau pemberi pekerjaan yang menggunakan layanan Jasa Konstruksi;

(3) Penyedia Jasa adalah pemberi layanan Jasa Konstruksi;

(4) Kontrak Kerja Konstruksi adalah keseluruhan dokumen kontrak yang mengatur hubungan hukum antara Pengguna Jasa dan Penyedia Jasa dalam penyelenggaraan Jasa Konstruksi;

(5) Kegagalan Bangunan adalah suatu keadaan keruntuhan bagunan dan/atau tidak berfungsinya bangunan setelah penyerahan akhir hasil Jasa Konstruksi;

Berdasarkan definisi - definisi di atas, maka pengertian kualitas pekerjaan konstruksi menurut penulis adalah kesesuaian persyaratan dan keinginan pada pelaksanaan pekerjaan konstruksi secara keseluruhan atau sebagian untuk mencapai hasil akhir sesuai dengan spesifikasi yang memuaskan pengguna jasa.

Soeharto, I (1995:1) proyek adalah suatu kegiatan sementara yang berlangsung dalam jangka waktu yang terbatas, dengan alokasi sumber daya tertentu dan dimaksudkan untuk melaksanakan tugas yang sasarannya telah digariskan dengan jelas.

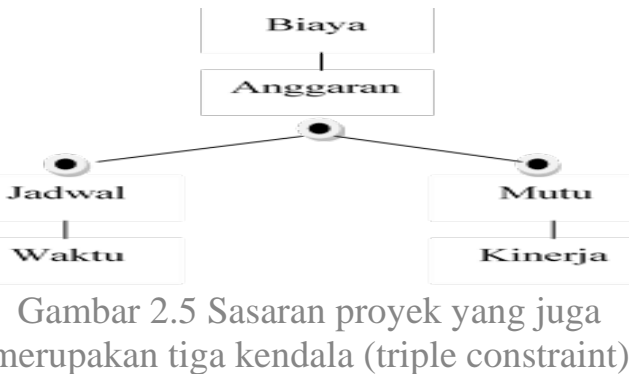

(Sumber : Soeharto, I (1995:2))

\section{Kerangka Pemikiran}

Dari uraian di atas, kerangka pemikiran penulis dalam melakukan penelitian ini dengan menggunakan pendekatan teori implementasi kebijakan model Charles $\mathrm{O}$. Jones, dimana kerangka pemikiran disajikan pada gambar 2.6 sebagai berikut :

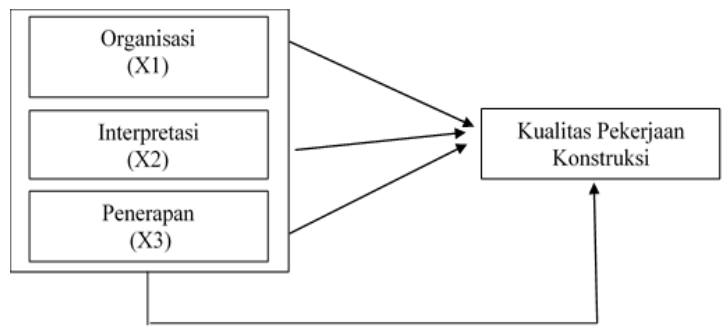

Gambar 2.6 Kerangka Pemikiran

\section{E. Hipotesis}

Berdasarkan uraian kerangka pemikiran, maka rumusan hipotesis dalam penelitian ini sebagaimana telah diuraikan dalam studi pendahuluan kepada PPK dan data lapangan perihal nilai penawaran di bawah $80 \%$ terdapat pengaruh terhadap kualitas pekerjaan konstruksi. Diantaranya sebagai berikut :

"Besarnya pengaruh implementasi kebijakan nilai penawaran di bawah $80 \%$ terhadap kualitas pekerjaan konstruksi di Kabupaten Bandung ditentukan oleh Organisasi, Interpretasi, dan Penerapan”.

\section{METODE PENELITIAN}

Penelitian ini merupakan penelitian kuantitatif dengan menggunakan metode survey explanatory dengan menggunakan teknik analisis deskriftif yang bersifat 
asosiatif kausal menggambarkan pengaruh dari variabel bebas (independent variable) terhadap variabel terikat (dependent variable) dengan pengujian hipotesis menggunakan analisis statistik uji-t, dan uji-f. Pengambilan sampel dalam penelitian ini menggunakan teknik probability sampling sebanyak 48 responden, dengan teknik pengumpulan data menggunakan kuisioner sebanyak 28 instrument pernyataan yang dinilai dengan skala Likert 1-5 dan dilakukan uji validitas serta reliabilitasnya. Dimana pengambilan sampel dalam penelitian ini menggunakan teknik probability sampling dengan menggunakan rumus dari Isaac dan Michael dalam Sugiyono $(2016 ; 67)$ tingkat kesalahan $5 \%$ dari populasi sebanyak 48 responden yang nilai penawarannya di bawah $80 \%$ dalam tender, maka jumlah sampel yang didapat sebanyak 42 sampel atas saran dan masukan sampel diambil seluruhnya sebanyak 48 sampel. Dimana teknik pengumpulan data menggunakan kuisioner sebanyak 28 item pertanyaan yang dinilai dengan skala Likert 15 dan dilakukan uji validitas serta reliabilitasnya terhadap Pejabat Pembuat Komitmen pekerjaan jasa konstruksi di Pemerintah Daerah Kabupaten Bandung pada Dinas Kesehatan 6 paket, Dinas Pendidikan 1 paket, Dinas Lingkungan Hidup 1 paket, dan Dinas Pekerjaan Umum Dan Tata Ruang 40 paket.

\section{HASIL DAN PEMBAHASAN}

\section{A. Pengujian Instrumen Penelitian}

Uji validitas bertujuan untuk mengukur valid atau tidaknya suatu indikator pertanyaan kuesioner. Dalam uji validitas corrected item-total correlation disebut sebagai nilai $r_{\text {hitung, dan untuk nilai } r_{\text {tabel }}}$ product moment dicari pada distribusi nilai $\mathrm{r}_{\text {tabel }}$ statistik yang didasarkan oleh nilai $\mathrm{df}$ (degree of freedom) dengan nilai df adalah n2. Maka dari 48 responden $\mathrm{df}$ adalah 48-2 = 46 , berdasarkan tabel product moment untuk $n$ 46 pada signifikasi $5 \%$ ketemu nilai $\mathrm{r}_{\text {tabel }}$ sebesar 0,285. Sesuai dengan dasar teoritis pengambilan keputusan untuk instrument di atas 0,285 maka dinyatakan valid dan untuk instrument yang memiliki nilai koefisien korelasi di bawah 0,285 dinilai tidak valid dan item pertanyaan tidak valid dapat dihilangkan.
Sedangkan untuk uji reliabilitas dilakukan dengan uji statistik Spearman-Brown Coefficient dengan metode split-half terhadap instrument yang valid untuk menilai kekonsistenan. Suatu konstruk dikatakan reliabel apabila memberikan nilai reliabilitas diatas 0,70 .

\section{B. Analisis Regresi Linier Berganda}

Analisis regresi linear berganda ini digunakan untuk mengetahui apakah implementasi kebijakan nilai penawaran di bawah $80 \%$ variable bebas dan varabel terikat memiliki pengaruh yang sangat besar terhadap kualitas pekerjaan konstruksi. Dimana analisis data menggunakan analisis regresi linier berganda diantaranya pengujian asumsi klasik, model regresi, analisis koefisien determinasi, uji simultan (f-test), dan uji parsial (t-test).

Maka didapat nilai konstanta dan koefisien regresi sehingga dapat dibentuk persamaan regresi linier berganda sebagai berikut:

$$
\begin{gathered}
\mathbf{Y}=\mathbf{a}+\mathbf{b}_{\mathbf{1}} \mathbf{X}_{\mathbf{1}}+\mathbf{b}_{2} \mathbf{X}_{\mathbf{2}}+\mathbf{b}_{3} \mathbf{X}_{3} \\
\mathrm{Y}=4,023+0,663\left(\mathrm{X}_{1}\right)+1,251\left(\mathrm{X}_{2}\right)+0,617
\end{gathered}
$$$$
\left(\mathrm{X}_{3}\right)
$$

Dimana :

$\begin{array}{ll}\mathrm{Y} & =\text { Kualitas Pekerjaan } \\ \text { Konstruksi } & \\ \mathrm{a} & =\text { Konstanta } \\ \mathrm{X}_{1} & =\text { Organisasi } \\ \mathrm{X}_{2} & =\text { Interpretasi } \\ \mathrm{X}_{3} & =\text { Penerapan } \\ \mathrm{b}_{1}, \mathrm{~b}_{2} & =\text { Koefisien regresi } \\ \varepsilon & =\text { error term }\end{array}$

Persamaan dari analisis regresi berganda yang tersaji di atas dapat dijelaskan sebagai berikut:

a) Konstanta sebesar 4,023 menunjukkan persentase skor kualitas pekerjaan konstruksi jika organisasi, interpretasi dan penerapan bernilai nol.

b) Koefisien regresi untuk variabel organisasi $\left(\mathrm{X}_{1}\right)$ adalah 0,663 yang menunjukkan besar perubahan persentase skor kualitas pekerjaan konstruksi yang dipengaruhi oleh organisasi, tanda positif menunjukkan pengaruh yang terjadi adalah searah artinya setiap terjadi peningkatan skor pada skor variabel Organisasi sebesar 
1 satuan dan variabel lainnya dianggap konstan, maka Kualitas Pekerjaan Konstruksi diprediksikan akan meningkat sebesar 0,663 satuan.

c) Koefisien regresi untuk variabel interpretasi $\left(\mathrm{X}_{2}\right)$ adalah 1,251 yang menunjukkan besar perubahan persentase skor kualitas pekerjaan konstruksi yang dipengaruhi oleh interpretasi, tanda positif menunjukkan pengaruh yang terjadi adalah searah artinya setiap terjadi peningkatan skor pada skor variabel Interpretasi sebesar 1 satuan dan variabel lainnya dianggap konstan, maka Kualitas Pekerjaan Konstruksi diprediksikan akan meningkat sebesar 1,251 satuan.

d) Koefisien regresi untuk variabel penerapan $\left(\mathrm{X}_{3}\right)$ adalah 0,617 yang menunjukkan besar perubahan persentase skor kualitas pekerjaan konstruksi yang dipengaruhi oleh penerapan, tanda positif menunjukkan pengaruh yang terjadi adalah searah artinya setiap terjadi peningkatan skor pada skor variabel Penerapan sebesar 1 satuan dan variabel lainnya dianggap konstan, maka Kualitas Pekerjaan Konstruksi diprediksikan akan meningkat sebesar 0,617 satuan.

Tabel 1. Hasil Koefisien Regresi

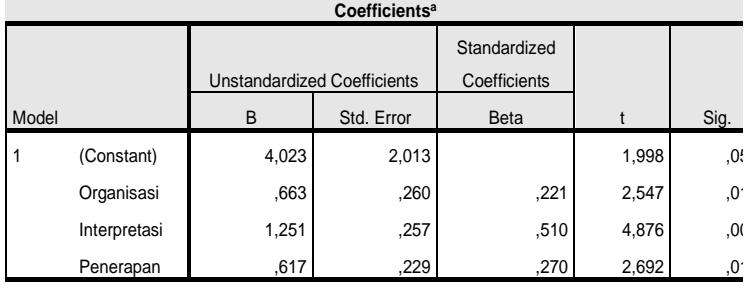

a. Dependent Variable: Kualitas Pekerjaan Konstruksi

(Sumber: Olah Data SPSS v.23, 2020)

\section{Uji Hipotesis}

\section{C.1. Uji Simultan (f-test)}

Maka didapat nilai $F_{\text {hitung }}$ sebesar 113,13 maka nilai $\mathrm{F}_{\text {hitung }}$ lebih besar dari $\mathrm{F}_{\text {tabel }}$ yaitu 113,13 > 2,816 selain itu diperoleh hasil nilai sig. sebesar 0,00 lebih kecil dari tingkat keyakinannya dari $0,00<0,05$ sehingga $\mathrm{H}_{0}$ ditolak. Dengan demikian model regresi berarti, sehingga secara simultan terdapat pengaruh yang signifikan antara implementasi kebijakan nilai penawaran di bawah $80 \%$ yang terdiri dari organisasi, interpretasi dan penerapan terhadap kualitas pekerjaan konstruksi di Kabupaten Bandung.

Tabel 1. Hasi Uji Simultan

\begin{tabular}{|ll|r|r|r|c|c}
\hline \multicolumn{1}{|l|}{ ANOVA $^{\mathrm{a}}$} \\
\hline 1 & Regression & Sum of Squares & \multicolumn{1}{c|}{ df } & Mean Square & \multicolumn{1}{c|}{ F } & \multicolumn{1}{c}{ Sig. } \\
\hline & Residual & 3100,334 & 3 & 1033,445 & 113,131 &, $000^{\mathrm{b}}$ \\
& Total & 301,936 & 44 & 9,135 & & \\
\hline
\end{tabular}

a. Dependent Variable: Kualitas Pekerjaan Konstruksi

b. Predictors: (Constant), Penerapan, Organisasi, Interpretasi

(Sumber: Olah Data SPSS v.23, 2020)

\section{C.2. Uji Parsial (t-test)}

Uji parsial (hipotesis) didapatkan hasil sebagai berikut : (1) Dimensi variabel organisasi terhadap kualitas pekerjaan konstruksi diperoleh nilai nilai thitung $>$ dari ttabel yaitu 2,547 $>2,015$ dan diketahui signifikasi sebesar 0,00 $<0,05$ sehingga $\mathrm{H} 0$ ditolak, yang artinya bahwa ada pengaruh dimensi organisasi terhadap kualitas pekerjaan konstruksi dengan arah positif. (2) Dimensi variabel interpretasi terhadap kualitas pekerjaan konstruksi diperoleh nilai nilai thitung $>$ dari ttabel yaitu 4,876 $>2,015$ dan diketahui signifikasi sebesar 0,00 $<0,05$ sehingga HO ditolak, yang artinya bahwa ada pengaruh dimensi interpretasi terhadap kualitas pekerjaan konstruksi dengan arah positif. (3) Dimensi variabel penerapan terhadap kualitas pekerjaan konstruksi diperoleh nilai nilai thitung $>$ dari ttabel yaitu 2,692 > 2,015 dan diketahui signifikasi sebesar 0,00 < 0,05 sehingga $\mathrm{H} 0$ ditolak, yang artinya bahwa ada pengaruh dimensi penerapan terhadap kualitas pekerjaan konstruksi dengan arah positif.

Tabel 1. Hasil Uji Parsial

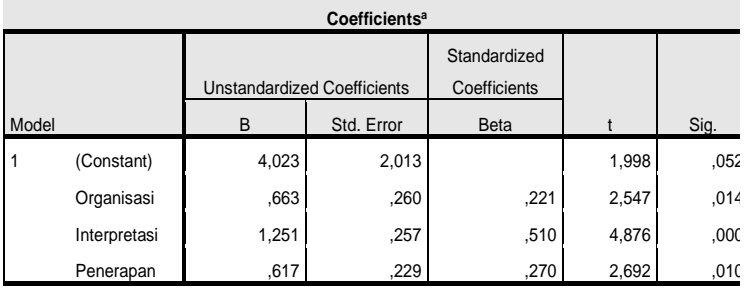

a. Dependent Variable: Kualitas Pekerjaan Konstruksi

(Sumber: Olah Data SPSS v.23, 2020)

\section{C.3. Analisis Koefisien determinasi}


Koefisien determinasi $\left(\mathrm{R}^{2}\right)$ pada intinya mengukur seberapa jauh kemampuan model dalam menerangkan variasi variable dependennya. Koefisien determinasi ini digunakan untuk melihat persentase pengaruh yang diberikan oleh Organisasi, Interpretasi dan Penerapan terhadap Kualitas Pekerjaan Konstruksi.

Tabel 1. Hasil Koefisien Determinasi

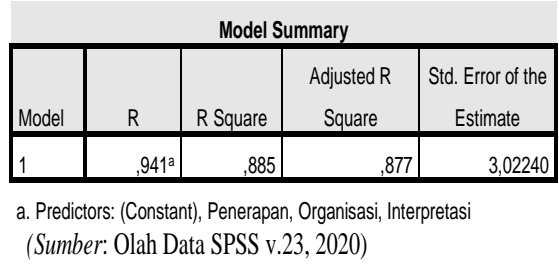

Berdasarkan Tabel 4.13 diperoleh nilai koefisien determinasi (Adjusted-R2) diperoleh sebesar 0,877 dengan presentase dari ketiga variabel bebas meliputi organisasi, interpretasi, dan penerapan sebesar 87,7 \%, sedangkan sisanya sebesar $(1-\mathrm{R} 2)=12,3 \%$ dijelaskan oleh sebab-sebab lain diluar model. Dimana rincian koefisien determinasi masing - masing adalah sebesar 49,9 \% dimensi variable interpretasi, $23,5 \%$ variabel Penerapan, dan 18,4 \% dimensi variabel organisasi.

\section{Pembahasan}

D.1 Implementasi Kebijakan Nilai Penawaran di Bawah 80 \% di Kabupaten Bandung

Berdasarkan teori yang dipakai dalam penelitian dari Charles O. Jones dalam implementasi kebijakan meliputi organisasi, interpretasi, dan penerapan. Kaitannya dengan proses Pengadaan Barang dan Jasa di Kabupaten Bandung merupakan sebuah rangkaian tindakan yang secara definitif berdasarkan undang - undang yang dilaksanakan oleh para implementor kebijakan untuk dapat mencapai tujuan yang diinginkan dalam menghasilkan penyedia barang jasa yang kompeten.

Dalam penerapannya implementasi kebijakan bagi para pelaku pengadaan barang dan jasa Pemerintah Daerah Kabupaten Bandung sudah sesuai dengan Peraturan Menteri Dalam Negeri Republik Indonesia
Nomor 112 Tahun 2018 yang ditinjau dari dimensi variabel organisasi, interpretasi, dan penerapan sudah cukup baik dan kompeten.

Organisasi Unit Kerja Pengadaan Barang/Jasa (UKPBJ) di Kabupaten Bandung. Meliputi sumberdaya, unit kerja, dan metode kerja sebagai implementor kebijakan adalah unit kerja pada Pemerintah Daerah Kabupaten Bandung yang menjadi pusat keunggulan pengadaan barang/jasa yang melaksanakan tugas pengkoordinasian pelaksanaan tugas, pelayanan administratif dan pembinaan Aparatur Sipil Negara di bidang Pengadaan.

Struktur kelembagaan Unit Kerja Pengadaan Barang /Jasa (UKPBJ) Kabupaten Bandung sudah terbentuk secara mandiri dan independen bukan adhoc yang berkedudukan di bawah sekretariat daerah dan bertanggungjawab kepada sekretaris daerah melalui asisten yang melaksanakan fungsi di bidang administrasi pembangunan. Dimana unit kerja UKPBJ Kabupaten Bandung sudah memiliki karakter yang strategis, kolaboratif, berorientasi pada kinerja, proaktif, dan mampu melakukan perbaikan sehingga mampu mendorong nilai tambah dan manfaat dalam kegiatan pengadaan barang/Jasa. Sumber daya manusia yang dimiliki UKPBJ Kabupaten Bandung dalam hal ini meliputi pokja pemilihan yang sudah ditetapkan oleh pimpinan UKPBJ untuk mengelola atau melakukan proses pemilihan penyedia, merupakan pegawai tetap yang sudah memiliki kompetensi sertifikat pengadaan barang dan jasa. Serta pelaksanaan/metode kerja dan proses pengadaan barang dan jasa oleh pokja pemilihan meliputi tugas dan kewenangannya sudah sesuai dengan Standar Oprasional Prosedur (SOP) dan kode etik pengadaan barang/jasa agar dapat berjalan sesuai dengan tujuan dan sasaran kebijakan guna memberikan kontribusi hasil yang diharapkan sesuai dengan ketentuan peraturan perundang-undangan.

Penjelasan, pendampingan, konsultasi, dan atau melalui bimbingan teknis dari sebuah implementasi kebijakan agar substansi program kebijakan tersebut mudah dipahami, sehingga menjadi sebuah rencana dan pengarahan yang tepat, serta dapat diterima dan dilaksanakan oleh para pelaku pengadaan merupakan interpretasi pengadaan barang/jasa. Melalui sosialisasi dan bimbingan teknis terhadap para stakeholder 
dari Perangkat Dinas dan pelaku pengadaan melalui UKPBJ menyampaikan penjelasan pelaksanaan tugas, fungsi, dan kewenangan yang terdapat dalam regulasi sebagai bentuk komitmen pelaku pengadaan.

Secara umum penerapan merupakan ketentuan atau acuan dalam sebuah pelayanan atau lainnya yang disesuaikan dengan maksud dan tujuan dari implementasi program kebijakan. Dalam penelitian ini penerapan kebijakan pengadaan barang dan jasa dan pelayanannya di Kabupaten Bandung sudah dilaksanakan secara optimal dan menyeluruh sesuai dengan regulasi yang dipakai yaitu dengan melakukan proses tender melalui aplikasi Sistem Pengadaan Secara Elektronik (SPSE) sehingga proses pengadaan menjadi : (i) menjadi lebih efektif, (ii) efisiensi anggaran, (iii) transparan, terbuka, dan bersaing untuk mendorong persaingan usaha yang sehat, (iv) berlaku adil yaitu dapat memberdayakan dan melindungi usaha kecil, (vi) dan akuntabel. Namun karena masih kurang dipahaminya regulasi pengadaan dan sistem yang ada, sehingga penyedia jasa yang merupakan bagian dari pelaku pengadaan masih banyak yang melakukan penawaran di bawah 80 \% dengan tujuan hanya untuk mendapatkan pekerjaan tanpa memprhitungkan efektifitasnya serta dampaknya terhadap pelaksanaan pekerjaan di lapangan.

Namun ada beberapa identifikasi kelemahan dari implementasi kebijakan nilai penawaran di bawah $80 \%$ dari mulai proses tender sampai dengan pelaksanaan pekerjaan. Diantaranya sebagai berikut :

Organisasi Meliputi sumber daya manusia para pelaku pengadaan meliputi Pejabat Pembuat Komitmen (PPK) dan Pokja Pemilihan walaupun sudah mempunai sertifikat kompetensi pengadaan barang/jasa, namun pengetahuan dalam masalah teknis konstruksi belum dianggap kompeten karena latar belakang pendidikanna bukan dari bidang keilmuan konstruksi.

Interpretasi Dalam pemahaman dan pandangan terhadap ketetapan regulasi

pengadaan barang/jasa
khususnya bagi penyedia
jasa dalam hal nilai
penawaran masih ada
perbedaan, hal tersebut
karena penyedia jasa hanya
bertujuan ingin
mendapatkan pekerjaan dan
menjadi pemenang tender
saja tanpa
memperhitungkan dampak
dan output dari penawaran
yang rendah di bawah 80
\%) secara teknis dan
pelaksanaanya.
Masih kurang maksimalnya
edukasi, sosialisasi, atau
bimbingan teknis kepada
para pelaku pengadaan baik
para stakeholder ataupun
penyedia jasa agar tender
jasa konstruksi menjadi
lebih kompeten bukan
hanya mendapatkan penedia
jasa yang penawarannya
paling rendah.

\section{D.2 Pengaruh Implementasi}

Hasil nilai koefisien determinasi (Adjusted-R2) yang diperoleh dalam penelitian ini berdasarkan analisis statistik secara parsial maupun simultan didapat sebesar 0,877 dengan kata lain besarna peresentase dimensi variabel kualitas pekerjaan konstruksi yang bisa dijelaskan oleh variabel bebas yaitu organisasi, interpretasi dan penerapan adalah sebesar 87,7 \%, sedangkan sisanya sebesar $(1-\mathrm{R} 2)=12,3 \%$ dijelaskan oleh sebab-sebab lain diluar model. Ini berarti implementasi kebijakan dari variabel bebas yang dipakai memiliki pengaruh yang signifikan dengan arah yang positif terhadap kualitas pekerjaan konstruksi di Kabupaten Bandung. Dimana besarnya pengaruh yang didapat dari masing - masing dimensi variabel organisasi, interpretasi, dan penerapan terhadap kualitas pekerjaan konstruksi yaitu untuk organisasi sebesar 18,4 $\%$, interpretasi sebesar 46,6 \%, dan penerapan sebesar 23,5\%.

Hal tersebut menunjukan bahwa semakin baik organisasi, interpretasi, dan 
penerapan kebijakan maka akan semakin baik pula kualitas pekerjaan konstruksi menjadi semakin tinggi, begitu pula sebaliknya semakin buruk organisasi, interpretasi, dan penerapan kebijakan maka akan semakin buruk pula kualitas pekerjaan konstruksi menjadi semakin rendah. Dengan kata lain untuk pengaruh yang signifikan adalah kalau implementasi kebijakannya diperbaiki, organisasinya ditingkatkan, interpretasinya diperbaiki, dan penerapannya diperbaiki maka akan mempengaruhi kualitas pekerjaan konstruksi menjadi lebih baik, sedangkan kalau tidak signifikan walaupun implementasi kebijakannya diperbaiki, organisasinya ditingkatkan, interpretasinya diperbaiki, dan penerapannya diperbaiki tetap saja kualitasnya tidak akan baik dan tidak akan berpengaruh.

Penerapannya dengan pekerjaan yang berkualitas merupakan kesesuaian persyaratan dan keinginan pada pelaksanaan pekerjaan konstruksi secara keseluruhan atau sebagian untuk mencapai hasil akhir sesuai dengan spesifikasi yang memuaskan pengguna jasa. Dalam proses pelaksanaan pekerjaan konstruksi, untuk mencapai tujuan dengan kualitas yang baik sesuai dengan keinginan owner (pemilik pekerjaan). Maka batasan pokok kualitas pekerjaan meliputi anggaran atau biaya yang dialokasikan, waktu pelaksanaan pekerjaan, serta mutu yang harus dipenuhi

Sesuai dengan tanggapan dari responden, estimasi merupakan hal yang paling utama dalam pelaksanaan proyek konstruksi, dimana estimasi digunakan untuk memperhitungkan, memperkirakan biaya dan urutan kegiatan. Dimana tujuan estimasi yang ingin dicapai dari pihak owner adalah untuk mendapatkan informasi yang sejelas-jelasnya tentang biaya yang harus disediakan untuk merealisasikan proyeknya, sedangkan tujuan estimasi dari penyedia barang/jasa (kontraktor) adalah untuk mengukur nilai penawaran terhadap proyek konstruksi.

Sesuai dengan hasil penelitian diatas, terbukti bahwa untuk dimensi variabel anggaran biaya nilai penawaran di bawah 80 $\%$ dinilai belum memuaskan, karena ternyata penawaran biaya yang baik atau kompetitif dalam tender jasa konstruksi adalah nilai penawaran yang mendekati nilai dari Owner Estimate (OE) atau harga perkiraan sendiri (HPS). Maka dari hasil tesebut, untuk dimensi variabel anggaran biaya proyek sudah tentu harus dapat dipertanggungjawabkan dan dapat ditunjang dengan aspek-aspek lain, yang berdampak dapat berpengaruh terhadap kualitas pekerjaan. Tahapan - tahapan dalam penyusun anggaran biaya yang kompetitif adalah sebagai berikut :

- Melakukan pengumpulan data tentang jenis, harga serta kemampuan pasar menyediakan bahan/material konstruksi secara kontinyu.

- Melakukan pengumpulan data tentang upah pekerja yang berlaku di daerah lokasi pekerjaan dan atau upah pada umumnya jika pekerja didatangkan dari luar daerah lokasi proyek.

- Melakukan perhitungan Analisa bahan dan upah dengan menggunakan Analisa sesuai dengan regulasi yang dipakai.

- Melakukan perhitungan harga satuan pekerjaan dengan memanfaatkan hasil Analisa satuan pekerjaan dan daftar kuantitas pekerjaan.

Bagian lain yang dapat berpengaruh terhadap kualitas pekerjaan konstruksi adalah perencanaan dan penjadwalan. Sesuai dengan hasil analisa diatas, bahwa penjadwalan digunakan untuk menggambarkan atau merepresentasikan proses dalam pelaksanaan pekerjaan sebagai tolak ukur untuk pengendaliaan proyek. Semakin baik perencanaan dan penjadwalan suatu proyek maka kualitas akan terjaga baik, karena pengeluaran biaya yang melebihi anggaran (cost overrun) dan keterlambatan (schedule delay) dapat diantisipasi dengan tindakan yang cepat dan tepat. spesifikasi dan material yang dipakai dapat terjadwalkan dan terdefinisi dengan jelas dan baik, sehingga kuantitas dapat sesuai dengan perencanaan serta kualitas sesuai dengan persyaratan.

Manfaat dan kegunaan penjadwalan atau penyusunan rencana kerja antara lain :

- Sebagai alat koordinasi dan kontroling;

- Sebagai pedoman kerja bagi para pelaksana untuk dapat berkoordinasi, dan kontroling terhadap pedoman yang dijadikan acuan dalam hal batas waktu yang telah ditetapkan untuk setiap item kegiatan. Karena kalau waktu pelaksanaan yang telah 
ditetapkan melebihi jadwal atau tidak konsisten maka dapat berpengaruh besar terhadap biaya yang sudah ditetapkan;

- Sebagai penilaian kemajuan pekerjaan, dimana ketepatan waktu dari setiap item kegiatan di lapangan dapat dipantau dari rencana pelaksanaan dengan realisasi pelaksanaan dan anggaran yang dikeluarkan;

- Sebagai evaluasi pekerjaan, variasi yang ditimbulkan dari pembandingan rencana dan realisasi dapat digunakan rencana dan realisasi agar dapat menentukan rencana selanjutnya;

Sedangkan kesesuaian mutu merupakan bagian terpenting sebagai sasaran pengelolaan proyek disamping biaya dan jadwal. Apabila biaya dan jadwal sudah bisa dikendalikan, maka kualitas pekerjaan konstruksi akan semakin baik dan terkendali. Dalam kegiatan konstruksi yang perlu diperhatikan dalam hubungannya dengan masalah mutu adalah sebagai berikut :

- Material konstruksi.

- Peralatan (equipment).

- Pelatihan dan sertifikasi tenaga konstruksi.

Dimana steatmen responden sudah jelas bahwa aspek mutu yang berkualitas dalam suatu pekerjaan konstruksi meliputi ketiga point diatas harus dilakukan terlebih dahulu dengan pengecekan, pengkajian, pemeriksaan/uji kinerja peralatan. Dalam pengkajian kualitas personil dan peralatan. meliputi : (1) peralatan tes dan pengukuran, (2) Teknik dan metode yang digunakan, (3) Standar dan kriteria yang diapakai.

Pengendalian kualitas dan kuantitas dari pemasok untuk item barang atau material yang dipakai meliputi : (1) Kemampuan pemasok, (2) Prosedur pemeriksaan material, (3) Pemeriksaan kualitas material dengan spesifikasi.

Selain faktor-faktor diatas yang harus diperhatikan dan dijalankan sesuai SOP nya dalam pelaksanaaan pekerjaan untuk menjaga kualitas pekerjaan konstruksi tetap baik sesuai dengan spesifikasi, namun hasil identifikasi penelitian yang menyebabkan kelemahan dari implementasi kebijakan untuk menjaga kualitas pekerjaan tetap baik adalah sebagai berikut, antara lain :

- Masih lemahnya pengawasan pekerjaan dilapangan dari para pihak (owner, konsultan, dan kontraktor pelaksana).

- Berita acara serah terima pekerjaan belum menggambarkan kondisi sebenarnya dengan pekerjaan yang terpasang di lapangan.

- Dikarenakan harga penawaran yang rendah, sehingga secara teknis berdampak kepada sumber daya proyek (personil tenaga proyek, dan metode pelaksanaan pekerjaan).

\section{KESIMPULAN DAN SARAN}

\section{Kesimpulan}

Berdasarkan hasil analisa dan pembahasan mengenai pengaruh implementasi kebijakan nilai penawaran di bawah $80 \%$ terhadap kualitas pekerjaan konstruksi di Kabupaten Bandung, maka penelitian ini dapat disimpulkan bahwa :

Pengaruh implementasi kebijakan nilai penawaran di bawah $80 \%$ terhadap kualitas pekerjaan konstruksi di Kabupaten Bandung bersifat signifikan yang ditinjau dari variabel bebas (independent variable) yang telah ditentukan dari segi organisasi, interpretasi, dan penerapan dengan didapatkannya hasil nilai koefisien regresi yang bernilai positif dengan nilai koefisien determinasi (Adjusted-R Square) yang diperoleh sebesar 0,877 dengan kata lain besar peresentase variasi kualitas pekerjaan konstruksi yang dihasilkan dari variabel bebas adalah sebesar 87,7 \% sedangkan sisanya sebesar $\left(1-\mathrm{R}^{2}\right) \quad=12,3 \%$ pengaruhnya ditentukan oleh model model lain diluar teori penelitian. Dengan kata lain pengaruh yang signifikan adalah kalaupun implementasi kebijakannya diperbaiki, dan juga variable dari organisasinya ditingkatkan, interpretasinya diperbaiki, dan penerapannya diperbaiki maka akan mempengaruhi kualitas pekerjaan konstruksi menjadi lebih baik, sedangkan kalau tidak signifikan walaupun implementasi kebijakannya diperbaiki, organisasinya ditingkatkan, interpretasinya diperbaiki, dan penerapannya diperbaiki tetap saja kualitasnya tidak akan baik dan tidak 
akan berpengaruh.

\section{Saran}

Diakarenakan penawaran di bawah 80 $\%$ berpengaruh terhadap kualitas pekerjaan konstruksi. Oleh karena itu, bagi para pelaku pengadaan sebagai implementor kebijakan dari berbagai kalangan stakeholders meliputi Organisasi Perangkat Daerah (PA/KPA, PPK, UKPBJ, dan APIP) dapat menjadi bahan pertimbangan untuk merumuskan kebijakan yang mampu meningkatkan kompetensi proses pengadaan barang/jasa, sekaligus untuk meminimalisir penawaran yang jumping/rendah agar tidak berpengaruh terhadap kualitas dimungkinkan dengan penambahan persyaratan kualifikasi penyedia dan persyaratan teknis penawaran. Dimana persyaratan tersebut harus mendapatkan persetujuan dari Pejabat Pimpinan Tinggi Pratama yang membidangi jasa konstruksi, dan oleh Pejabat Pimpinan Tinggi Pratama yang merupakan unsur pengawas dalam penyelenggaraan pemerintahan daerah.

Untuk akademis khusnyai di bidang kebijakan publik, dalam penelitian selanjutnya diharapkan untuk dapat menambahkan variabel lain diluar teori yang diyakini dapat mempengaruhi kualitas pekerjaan konstruksi sehingga memberikan hasil yang lebih luas. Dan juga dapat mengembangkan penelitian ini dengan menggunakan metode lain dalam penelitian, sehingga informasi yang diperoleh dapat lebih beragam selain dari kuisioner dengan jawaban yang telah disediakan.

\section{DAFTAR PUSTAKA}

Buku - Buku

Abidin, Said Zainal. 2016. Kebijakan Publik Edisi 3. Jakarta : Penerbit Salemba Humanika.

Dunn, William N. 2003. Pengantar Analisis Kebijakan Publik Edisi Kedua. Yogyakarta : Gadjah Mada University Press.

Ervianto, Wulfram I. 2005. Manajemen Proyek Konstruksi (Edisi Revisi). Yogyakarta : Penerbit Andi Offset.

Jones, O. Charles. 1994. Pengantar Kebijakan Publik Cetakan Kedua. Jakarta : Raja Grafindo Persada.

Sugiyono. 2016. Cara Mudah Menyusun
Skripsi, Tesis, dan Disertasi. Bandung : Penerbit Alfabeta.

Subarsono. 2005. Konsep, Teori Dan Aplikasi Analisis Kebijakan Publik. Yogyakarta : Pustaka Pelajar Yogyakarta.

Soeharto, Iman. 1995. Manajemen Proyek Dari Konseptual Sampai Operasional. Jakarta : Penerbit Erlangga.

\section{Perundang - Undangan}

LKPP. 2018. Peraturan Presiden RI Nomor 16 Tahun 2018 Tentang Pengadaan Barang/Jasa Pemerintah. Jakarta : Lembaga Kebijakan Pengadaan Barang/ Jasa Pemerintah.

LKPP. 2018. Peraturan Lembaga Kebijakan Pengadaan Barang/Jasa Pemerintah (LKPP) Nomor 9 Tahun 2018 tentang Pedoman Pelaksanaan Pengadaan Barang/Jasa melalui Penyedia. Jakarta : Lembaga Kebijakan Pengadaan Barang/ Jasa Pemerintah.

PUPR. 2019. Peraturan Menteri Pekerjaan Umum Dan Perumahan Rakyat Republik Indonesia Nomor 07/PRT/M/2019 tentang Standar Dan Pedoman Pengadaan Jasa Konstruksi Melalui Penyedia. Jakarta : Kementerian Pekerjaan Umum dan Perumahan Rakyat.

PUPR. 2020. Peraturan Menteri Pekerjaan Umum Dan Perumahan Rakyat Republik Indonesia Nomor 14 tahun 2020 tentang Standar Dan Pedoman Pengadaan Jasa Konstruksi Melalui Penyedia. Jakarta : Kementerian Pekerjaan Umum dan Perumahan Rakyat.

\section{Jurnal}

Akhir, Abdi. 2019. ”Pengaruh Implementasi Kebijakan Standar Pelayanan Minimum Terhadap Kualitas Pelayanan Pendididkan Pada Fakultas Ilmu Sosial Dan Politik”. Universitas Tadulako 